\title{
"Você não é piedoso" - A Piedade Cristã e o desafio do Humanismo: breve ensaio a propósito de um texto clássico de Lucien Febvre sobre Lutero (e Erasmo).
}

\author{
"Du Bist Nicht Fromm" - Christian Piety and Humanism challenge: short essay \\ the purpose of a classic text Lucien Febvre on Luther (and Erasmus).
}

Ronaldo de Paula Cavalcante*

\begin{abstract}
Resumo
A piedade cristã fez um longo percurso histórico, desde a antiguidade, com base no judaísmo e no diálogo com a filosofia grega. De certa forma a Idade Média estabelece uma ruptura parcial com esse patrimônio. Lutero, formado nessa tradição medieval, porém iluminado por suas recentes experiências pessoais, relativiza o cerimonialismo que se formou na cristandade e sublinha, por um lado, sobretudo, a soberania e majestade de Deus, e por outro, a miséria humana, redimida somente pela graça divina. Erasmo igualmente rejeita boa parte do medievo e escolástica, porém, propõe como caminho de salvação a educação como formação do caráter cristão. Em dado momento, os dois gênios, que possuíam uma simpatia mútua, não puderam mais impedir que se manifestassem as diferenças das propostas. Lucien Febvre enfrenta a tarefa discutir o encontro entre a dignidade divina (Lutero) e a dignidade humana (Erasmo) que nós aqui retomamos em forma de ensaio.
\end{abstract}

Palavras-chave: Erasmo, Lutero, Lucien Febvre, Piedade cristã, Humanismo.

\begin{abstract}
Christian piety has a long historical journey, from ancient times, based on Judaism and dialogue with Greek philosophy. Somehow Middle Ages establish a partial rupture with this heritage. Luther, formed in the same tradition, but illuminated by his recent personal experiences, relativized ceremonialism which was settled in Christianity and emphasized, on the one hand, especially the sovereignty and majesty of God, and on the other, human misery, only redeemed by divine grace. Erasmus also rejects much of the Middle Ages and scholasticism and proposes education as a way of salvation and formation of Christian character. At one point, the two geniuses, who had a mutual sympathy, could not prevent differences in their proposals from manifesting themselves. Lucien Febvre faces the task of discussing the encounter between the divine dignity (Luther) and human dignity (Erasmus) which we here retake in the form of an essay.
\end{abstract}

Keywords: Erasmus, Luther, Lucien Febvre, Christian piety, Humanism.

Artigo submetido em 04 de maio de 2016 e aprovado em 16 de novembro de 2016.

* Doutor em Teologia Dogmática pela Universidad Pontifícia de Salamanca e pós-doutor em Teologia Pública pelas Faculdades EST. É professor titular no mestrado em Ciências das Religiões da Faculdade Unida de Vitória-ES. Atualmente está como Visiting Scholar no PTS - Princeton Theological Seminary - Princeton-NJ-EUA. País de Origem: Brasil. E-mail: ronaldo@faculdadeunida.com.br 


\section{Introdução}

O presente ensaio busca rediscutir a temática da espiritualidade cristã localizada na fronteira entre o medievo, já em seu "outono" e a modernidade nascente. Por um lado, um património espiritual milenar conduzido por uma instituição eclesiástica posto na berlinda, por outro, o desafio das novas ideias oriundas do humanismo renascentista, ainda ligado a essa mesma instituição, mas que, pouco a pouco desgarrava-se redescobrindo o indivíduo. Ideias que agora chegavam finalmente no mundo hermético da teologia, última "cidadela a ser conquistada”. De fato, antes de 1517 várias reformas já estavam em curso $^{1}$, inclusive as novas possibilidades de se ler o texto sagrado a partir de suas línguas originais, como parte do movimento ad fontes, que almejava recuperar a cultura clássica grega e romana antigas. O Latim e o texto da Vulgata (tradução de São Jerônimo no sec. IV) não seriam descartados, porém não mais teriam a primazia para as interpretações e conclusões teológicas e dogmáticas. É sempre bom lembrar que a publicação do Novo Testamento Grego $^{2}$ de Erasmo de Roterdã, não obstante suas limitações, corrigidas nas edições subsequentes, deu-se em 1516, portanto, cerca de um ano antes da deflagração da Reforma. Isso indica que uma mudança significativa do cristianismo ocidental já estava a caminho em fins do século XV e inícios do século XVI. O próprio Erasmo havia publicado seu importante Enchiridion Militis Christiani (Manual do soldado cristão em 1503) pregando uma laicização educada e letrada do cristianismo, rompendo com a hegemonia cultural do clero e do monaquismo que perdurava por mais de um milênio.

Com todo esse pano de fundo em mente, Lucien Febvre, o genial historiador francês e co-fundador da Escola dos Annales, em 1927 publicou uma de suas principais obras: Un destin: Martin Luther. Documento seminal sobre a personalidade de Lutero e sobre a Reforma. Partiu de uma abordagem

\footnotetext{
${ }^{1}$ Sobre isso ver MacGrath, 2012,p. 29-41.

${ }^{2}$ Impresso em Basiléia na Suiça, com base na compilação do textus receptus, utilizando diversos manuscritos e inclusive apontando as variantes textuais. Esta publicação se tornaria na principal fonte para as ulteriores traduções mais aprimoradas. Apesar de causar grande celeuma entre as autoridades eclesiásticas, a solidez de sua tradução foi confirmada posteriormente. Lutero o utilizou como base para a sua tradução concluída em 1522.
} 
historiográfica crítica rigorosa buscando nas fontes, especialmente alemãs, um balizamento seguro, contudo se distanciando tanto das biografias tradicionais, quanto das pre-compreenssões teológicas ou ideológicas, que mitificavam ou demonizavam Lutero. De forma surpreendente Febvre centrou-se no caráter psicológico de Lutero, em suas dúvidas pessoais, como que descrevendo o próprio caráter germânico moderno em sua gênese. Nesse sentido, ainda que tivesse repercussões coletivas, o fenômeno Lutero, segundo Febvre, é fruto muito mais de sua verve religiosa pessoal, individual, obviamente contraposta ao status quo católico alemão. Em dado momento, não conseguiu mais represar suas descobertas, manifestando sua intimidade com Deus em atos, tratados, cartas, comentários exegéticos, aulas e, sobretudo, em corajosas diatribes proféticas desafiadoras.

Assim, o Lutero de Febvre é antes de tudo um idealista puro, que não consegue dimensionar as consequências sociais de seus atos e por isso mesmo não se intimida, age mais como um profeta do que um político maquiavélico. Sabrina Rocha, em sua esclarecedora resenha sobre Martinho Lutero: um destino oportunamente sublinha que segundo Febvre: "ele permanecia magnífico e ingênuo, um idealista absoluto que se colocava acima das misérias do mundo real" (ROCHA, 2014, p. 280-286), conclusões sobre a personalidade de Lutero que de forma clara ecoam os ditos de Lucien Febvre acerca do reformador alemão. Em 1949, contrapondo-o a Erasmo, afirmou: "Martinho Lutero leva em seu interior um ingênuo anarquismo, um horror à lei que engendra rebeldia... Não, a doutrina de Lutero não é a de Erasmo; e mais, o homem Lutero não é o homem Erasmo"3. Citando a Groethuysen, pontua ainda que, diferentemente do super-homem do renascimento que prescinde de Deus, o homem de Erasmo é "religioso por modéstia”, e este é outro aspecto que o separa do reformador.

\footnotetext{
${ }^{3}$ Conferência pronunciada no Rio de Janeiro em agosto de 1949, intitulada: "Erasmo e sua época". Posteriormente recolhida em Lucien Febvre, 1970, p. 95.
} 


\section{Os Antecedentes - Síntese}

No ambiente teológico cristão ocidental já maduro, é consenso que o início propriamente dito da piedade numa opção mística, como intelligentia fidei compreensão dos mistérios da fé (fides quae) está vinculada à teologia do PseudoDionísio Areopagita4. Apesar do caráter eminentemente extático que lhe dá esse autor, no sentido de que o homem é arrebatado acima de si e "percebe (do Latim experiri) que com ele está presente mais do que com ele próprio" (MIETH, 1993, p. 564) sobressai como centro e origem do fenômeno místico, o Cristo encarnado. Quando se fala, pois, em história da mística cristã deve-se partir de uma abordagem teológica da encarnação tendo como locus fundante a experiência de Jesus de Nazaré - o Jesus histórico, ainda que transmitido pela tradição - o Cristo dafé.

Não importando seja descrita no paradigma da visão contemplativa e afetiva ou do nascimento de Deus no coração e do renascimento de Cristo na alma, evidente está que quanto à legitimidade da mística cristã pode-se afirmar, contra Harnack (1961, p. 64), para quem o helenismo, além dos cultos mistéricos e esotéricos seria sua fonte, que na própria teologia paulina está presente uma mística de Cristo - conforme destacado por A. Schweitzer (2003) e A. Deissmann (1957, p. 147-157), antes dele, por exemplo. Ademais, no Evangelho de João se utiliza os termos "ver e conhecer" pela fé, de forma que antecipa igualmente elementos de uma via unitiva para a ulterior mística cristã. Tais referências preliminares nos levam diretamente à Escritura, uma vez que "toda Sagrada Escritura está aberta a uma interpretação mística” (FISCHER, 1973, p. 727). Sendo assim, o Antigo Testamento sublinharia tanto a experiência de fé, como os encontros de Deus com Moisés (na sarça e no Sinai). Os encontros dos profetas com Deus (teofanias de Yahweh) que são sempre visão, chamamento e missão aos

\footnotetext{
${ }^{4}$ Nome de um autor, possivelmente sírio, fazendo-se passar por um discípulo do apóstolo Paulo, mas que na verdade deve ter vivido nas fronteiras dos séculos V e VI, cujas obras: Nomes divinos, Duas hierarquias e Teologia mística de influência claramente neoplatônica e mística, tornaram-se bem conhecidas na Idade Média graças a pensadores como Máximo o Confessor (séc. VIII) e João Scotus Eriúgena (Sec. IX).
} 
outros e para os outros, além, é claro das figuras de Abraão, Jacó, Elias e tantos mais que experimentaram um tipo de comunhão imediata com Deus. Sobre esse material da Escritura, principalmente Paulo e João, é que se debruçará toda a patrística, desde os alexandrinos: Clemente (GOMES, 1980, p. 140), alegoriza misticamente sua "verdadeira” gnose: "Ó Jesus Cristo, leite que nos desceu do céu pelos sagrados seios da esposa virginal, premida pelos dons da eterna sapiência”. Em seu momento, Orígenes (QUASTEN, 1991, p. 410)5, igualmente, lê o Cântico com lentes alegóricas e descreve o caminho da alma no encontro com Deus: “Consideremos a alma cujo único desejo é unir-se e juntar-se com o Verbo de Deus e entrar nos mistérios de sua sabedoria e de sua ciência, como no tálamo de um esposo celeste. A esta alma, já foram entregues seus dons, como um dote”.

Também, passando pelo capadócio, Gregório de Nissa (“pai da mística”), como por exemplo, no seu Cântico dos Cânticos ${ }^{6}$, e, é claro, por Santo Agostinho,

A alma após esse trabalho, ou seja, após ser liberta e purificada de toda mácula e de toda sujeira, ela se alegra consigo mesma e não mais teme por si nem se tormenta em relação a si. Este é então o quinto degrau... A alma neste estágio compreende bem como é grande, cheia de uma imensa e inacreditável confiança, ela corre em direção a Deus, ou seja, em direção à contemplação da própria verdade, em direção a esta grande e sublime misteriosa recompensa pela qual ela tanto lutou (SANTO AGOSTINHO, 2016, n. 70 e 74).

Finalmente, chegando ao Pseudo-Dionísio7 Areopagita, dando cores definitivas a essa tradição: “Abandona os sentidos e as operações intelectuais, todo o sensível e o inteligível, tudo o que não é e o que é, e na medida do possível, pela via da negação, estende-te para a união com aquele que está por cima de toda substância e de todo conhecimento”.

Tal tradição, Lutero conheceu bem, de leituras e de vivências no mosteiro agostiniano de Erfurt na Alemanha. Porém, nos escritos de 1520 torna-se um

\footnotetext{
${ }^{5}$ Comm. In Cant 1.

${ }^{6}$ San Gregorio de Nisa. Comentario al Cantar de los Cantares. Salamanca: Sígueme, 1993, p. 16, onde diz: "Purificado o coração de formas rotineiras e das aparências da vida, o Cântico dos Cânticos nos encaminha misticamente pela senda do divino. Se procede com linguagem nupcial, que se deve entender como diálogo de amor entre Deus e a alma".

${ }^{7}$ Theol. Myst. I,1, (SPANNEUT. 2002, p. 299).
} 
crítico feroz da mística, especialmente de Dionísio, diz ele, "Quanto à Teologia mística, à qual alguns dos mais ignorantes pseudoteólogos concedem tanta importância, também é muito perniciosa, pois é mais platonizante que cristianizante" (LUTERO, 1989, p. 412).

Em seguida, o medievo tem no seu primeiro momento uma fase de florescimento (séculos VIII e IX), especialmente no período carolíngio, com a recepção e tradução para o latim desse patrimônio patrístico de espiritualidade. Mais que uma ênfase apenas nos rituais sobressai os aspectos morais e éticos postos como condições necessárias. A obra (na verdade, um estilo literário) Specula principis (Espelhos do príncipe) do séc. IX destaca os deveres do Estado e o poder político-econômico “em favor da Igreja e dos fracos” (VAUCHEZ, 1995, p. 19), ressaltando as virtudes da justiça e da misericórdia. Entretanto, a piedade cristã experimenta uma decadência espiritual por conta das controvérsias doutrinais (também nos séculos VIII e IX)8, porém, se recupera nos séculos XI a XIII. Com isso, a alta Idade Média, no contexto dessa renovação espiritual, redescobre a "humanidade de Cristo", principalmente com São Bernardo e sua célebre interpretação do Cântico dos Cânticos, de certa forma reeditando Orígenes e outros - a denominada "mística nupcial"9. Como também Guilherme de Saint-Tierry1o e a notável mística alemã, Hildegard von Bingen ${ }^{11}$ sem esquecer a abadia de São Victor, com Ricardo e Hugo, e ainda Alred de Rievaulx e Isaac de Estrela. Em todos eles a alma sente-se como noiva preparada para seu noivo. Curioso paradoxo em que se funda uma tradição de espiritualidade mística e espiritualizante tendo como matriz o Cristo encarnado e seu término no Verbo divino!

\footnotetext{
${ }^{8}$ Ver Vilanova, 1987, que relaciona as seguintes controvérsias: filioque, iconoclasta, eucarística e predestinacionista.

${ }^{9}$ A doutrina mística de S. Bernardo de Claraval pode ser encontrada principalmente no Tratado do Amor de Deus e nos Sermões do Cântico dos Cânticos (total de 86 sermões). Ponto culminante dessa doutrina é o matrimônio místico ou unio mystica. Na primeira obra, Bernardo enumera os quatro graus do amor a Deus: Amor carnal, Amor interessado por Deus, Amor desinteressado por Deus, Amor puro por Deus. (San Bernardo, 1993, p. 332-343. Sobre esse último grau, nos Sermões, declara: "Dá-me agora uma alma familiarizada com a visita do Verbo esposo: isso a tornará corajosa". (Sermão 74, num. 3), em San Bernardo, 1987, p. 927.

${ }^{10}$ Monge cisterciense, colega de hábito de São Bernardo. Especialmente suas obras: De contemplando Deo e Brevis commentatio in Canticum canticorum.

${ }^{11} \mathrm{Em}$ particular, sua trilogia de teologia mística, Liber scivias Domini dividida em três volumes contendo um total de 26 visões. Felizmente já dispomos em Português em uma excelente edição: Bingen, 2015.
} 
Uma Mística da Essência ${ }^{12}$, mais especulativa - wesenmystic - desenvolvese nos sécs. XIII e XIV e advoga a união do ser criado no ser originário. Aqui, experiência espiritual é o encontro com Deus no fundo da alma = Neoplatonismo Cristianizado (Evágrio/Agostinho/Pseudo-Dionísio). Trajetória culminada na mística renano-flamenga de Meister Eckhart, Johannes Tauler, Heinrich Suso e Jean Ruysbroek, com ramificações em muitos movimentos populares e laicos. Neles a ciência teológica se fez mística. Não lhes preocupa só a indagação do caminho para Deus, senão demonstrar suas possibilidades últimas e chegar ao fundo metafísico da alma onde se realiza a união com Deus. Paralelamente, nos sécs. XII a XIV surgem vários agrupamentos e associações laicas cristãs: begardos, beguinas, Irmãos do livre espírito, Gottes Freunde, quase todos suspeitos de heresia e de fato condenados. Em especial as duas ordens mendicantes: dominicanos e franciscanos. Tais grupos serão objeto dos cuidados pastorais dos grandes teólogos. Sobre Lutero e sua ideia de liberdade, exerce significativa atuação a obra intitulada por ele "Teologia alemã", de autor anônimo e influenciada pelos místicos especulativos, em especial Eckhart e surgida em Frankfurt no final do século XIV.

Outro caminho traçado da piedade cristã é o da Devotio Moderna ${ }^{13}$ nos sécs. XIV - XVI. Reage às especulações dos renanos e prefere a espiritualidade mais afetiva. É devotio por aceder à verdadeira piedade, mais vivida que intelectualizada. É moderna, porém, está na linha afetiva de Agostinho, Gregório, Bernardo, os franciscanos, os cartuxos. De fato, Lutero possui aspectos desses dois momentos, ele está na transição dos tempos. Consegue ser bem moderna sua valorização da língua alemã como veículo dos mistérios de Deus e simultaneamente a filosofia platônica mostra-se presente em suas leituras de S. Bernardo e S. Boaventura, principal teólogo fransiscano. A leitura piedosa e popular da Devotio é cristocêntrica se interessando especialmente pela vida histórica de Jesus, pela meditação nos mistérios da humanidade de Cristo, meio para contemplação. Possui

\footnotetext{
${ }^{12}$ Sobre a Mística cristã em geral e a da Essência, recomendo: McGinn, 2006; McGinn, 2013; e Maroto, 1990.

${ }^{13}$ Sobre Devotio Moderna, ver: John van Engen, 1988.
} 
uma tendência prática e ascética. Perde profundidade, porém ganha em simplicidade e alcança mais adeptos universalizando a piedade. Propõe passos na oração: lectio, meditatio, oratio, contemplatio (Guigo II séc. XII). Alguns representantes são: G. Groote (1340-1384); Florencio de Radewijns (1350-1400); Tomás de Kempis (1380-1471), com sua Imitatio Christi, igualmente os Irmãos da Vida Comum.

Por fim, a Mística Esponsal - brautmystic que parte do patrimônio bíblico e cristão, fundamentando-se na idéia da aliança e da simbologia nupcial - comunhão da esposa com o esposo - disponibilidade e entrega total - estar unido em Cristo. Os antecedentes dessa interpretação, como já dito, podem ser encontrados, particularmente em Gregório de Nissa, Orígenes de Alexandria e mais tardiamente em Bernardo de Clairvaux e Guilherme de St. Tierry, já mencionados. Nessa linha os maiores expoentes são: Catarina de Sena, Teresa de Ávila e João da Cruz.

De qualquer maneira, decisivo não é mais a gnose mística, (muito embora se ressinta ainda aqui de um neoplatonismo cristianizado), mas o afeto (cistercienses, franciscanos, Matilde de Magdeburgo, Henrique Suso, Juliana de Norwich e por fim a mística espanhola, contemporânea de Lutero), como marca do discípulo de Jesus de Nazaré. Em Lutero, pois, converge tanto uma corrente espiritual com vários matizes, como também um tipo de biblicismo que procede de Wycliff e seu tratado, De ecclesia - a igreja como comunio predestinatorum, além do lastro filosófico do ockhamismo presente em sua formação agostiniana em Erfurt. De fato, o filósofo e sacerdote franciscano, Guilherme de Ockham (1295-1349) surge como um pensador bem original e antecipador dos tempos modernos. A partir de ideias de Duns Scotus, um colega de hábito fransciscano, adotava o voluntarismo como concepção filosófico-jurídica e, em meio à discussão acerca dos universais, "descobre" o particular, o individual, vitalizando sobremaneira o movimento filosófico do nominalismo. Para ele, fora da mente e da linguagem humana, os universais inexistem. Como esclarece Tarnas, "Ockham argumentava que nada existia, a não ser os seres individuais, que somente a 
experiência concreta poderia servir de base ao conhecimento" (TARNAS, 2008, p. 225). A particularização na ação epistemológica assume o comando na investigação exigida pelos novos tempos, que já se avizinhavam fazendo da experiência (empirismo) a única fonte legítima de conhecimento.

O movimento nominalista e a ênfase no indivíduo tornam consciente o processo de individuação, proporcionando "o reconhecimento do livre-arbítrio humano individual e, especialmente, da liberdade de Deus de escolher como criava cada indivíduo; a existência de Deus ou do homem” (TARNAS, 2008, p. 226). Nessa nova concepção filosófica, tais realidades não estariam mais ligadas ao determinismo de conceitos fixos, num sentido tomista ou aristotélico. Em Ockham, a fé em Deus deve estar separada do conhecimento empírico-científico, para que ambos se desenvolvam, mantendo-se a integridade de cada qual. Por isso mesmo, sua abordagem será conhecida como via moderna, nada mais correto! Assim, a descoberta do indivíduo torna-se a chave hermenêutica que iria abrir as portas da modernidade, sendo inclusive a conexão filosófica mais importante com o advento da Reforma protestante. O historiador Herman Tüchle, fazendo um resumo das ideias de Lutero identifica que as mesmas "são próprias do nominalismo radical, às quais se acrescenta ideias da escola agostiniana e influxos da mística alemã que colaboram com as experiências pessoais de Lutero" (TÜCHLE, 1987, p. 66). Assim, não seria exagero aceitar que em Lutero temos uma convergência de fatores e influência e que ele conseguiu como poucos equilibrar em sua piedade. Se Erasmo privilegiou sobremaneira a mente e o intelecto, Lutero integrou intelecto e afeto de maneira magistral, eu diria. Birgit Stolt, salienta isso ao falar sobre a "fé do coração" de Lutero, "Coração, para ele, abrange intellectus et affectus, a razão e a emoção... o sentimento é uma forma de conhecimento. O coração não é somente ardente e apaixonado, mas também sábio” (STOLT, 2013, pp. 152, 157).

Uma aproximação ao protestantismo histórico revela num primeiro momento e de maneira mais periférica, uma posição de rejeição para com qualquer tipo de misticismo cristão uma vez que para tal protestantismo o princípio da sola 
scriptura reduz ao plano objetivo, qualquer tentativa de comunhão com o Sagrado, não havendo, portanto, possibilidades outras de experiência de fé subjetiva. Contudo, a partir de uma leitura tanto de Lutero como da tradição que o segue, pode-se constatar a presença e o influxo da mística cristã no movimento reformista. De fato, no reformador de Wittemberg podemos constatar não apenas uma mística, mas uma "reformulação da vivência mística da paixão do Senhor distanciada do modelo medieval que se apoiava sobre a imitatio Christi e o seguimento de sua paixão que ele supera ou transforma” (MONTES, 1987, p. 169). Paul Tillich, ainda que inicialmente, coloque o misticismo sob suspeição, posteriormente propõe que o locus protestante como poder da Igreja "é simbolizado pela cruz; na cruz a humanidade experimentou a situação limite de maneira única. Nesse poder, na verdade, nessa impotência e pobreza a igreja protestante haverá de se manter na medida em que tiver consciência do significado de sua existência” (TILLICH, 1985, p. 216)14. A afirmação de um locus místico na Reforma, por meio da doutrina da justificação pela fé, por parte de Tillich é de maneira original e criativa confirmada por Thompson quando analisa o "Cântico" de São João da Cruz. Por outro lado, avalia negativamente a posição de Barth, como que concluindo que no luteranismo sim (há um locus), no calvinismo não (THOMPSON, 1963, p. 219) ${ }^{15}$. Um claro exemplo de mística na tradição protestante (anglicana) é Evelyn Underhill (1875-1941), suas obras Mysticism (1911) e Worship (1936), são claros exemplos dessa corrente. Porém, a ruptura reformada com o catolicismo e sua tradição mística de fato teve um alcance maior e, por isso mesmo, o diálogo se fez mais difícil até aos dias de hoje.

\footnotetext{
${ }^{14}$ Esta inserção em Cristo está representada sobremaneira na teologia crucis de Lutero que ele desenvolveu logo em seguida à questão das indulgências. Gerhard Ebeling é certeiro quando esclarece que com base no pensamento paulino, Lutero entendia a teologia da cruz como "o critério e o lugar de verdadeira teologia... o teólogo da cruz, diz ele, fala do Deus crucificado e oculto... ele é o Deus crucifixus e absconditus" (EBELING, 1988, p. 180-181. Sobre a teologia da cruz é indispensável: Walter von Loewenich, 1988.

${ }^{15} \mathrm{E}$ acrescenta: "Aunque protestantes ambos, cada uno mantiene una actitud teologica distinta hacia el misticismo y representan en muchos sentidos puntos de vista opuestos" (THOMPSON, 1963, p. 219). Sobre a espiritualidade reformada ver, por exemplo: RICE, 1991.
} 


\title{
2 O destino de Lutero
}

Voltemos a Lutero. Acerca da mística cristã em perspectiva de união esponsal, em seu tratado sobre “A liberdade cristã” (1520), Lutero escreve:

\begin{abstract}
A terceira incomparável graça da fé é esta: a alma é copulada com Cristo como a noiva com o noivo, sacramento pelo qual (como ensina o apóstolo) Cristo e alma são feitos uma só carne. Sendo eles uma só carne, é consumado entre eles o verdadeiro matrimônio, sim o mais perfeito de todos, enquanto os matrimônios humanos são figuras tênues desse matrimônio único. Daí se segue que tudo se lhes torna comum tanto as coisas boas quanto as más, de modo que a alma fiel pode apropriar-se e gloriar de tudo que Cristo possui como sendo seu, e de tudo que tem a alma, Cristo se apropria como se fosse seu.... Pois se ele o noivo, tem que, simultaneamente, aceitar o que é da noiva e compartilhar com a noiva o que é seu... assim alma do crente se torna livre de todos os pecados pelas arras de sua fé em Cristo, seu noivo a segura contra a morte e protegida do inferno, presenteada com eterna justiça, vida, salvação de seu noivo Cristo (LUTERO, 1989, p. 442).
\end{abstract}

Esse é o mundo de Lutero. Mas ele não estava sozinho, encapsulado e isolado das novas ideias e propostas de reforma religiosa, política e educacional. Seu contato com o humanismo dava-se por meio de Melanchthon, sobrinho de Johannes Reuchlin, o principal humanista alemão daquele momento. F. Lau essevera que "O entusiasmo de Lutero sobre as "línguas" é fruto da amizade com Melanchthon e do humanismo que através deste atuava sobre Lutero" (LAU, 1974, p. 72). Colaboradores próximos como Justo Jonas e Jorge Espalatino igualmente mantinham Lutero em contato com as ideias e inovações do humanismo, havendo, pois, uma imbricação entre o princípio da sola scriptura luterano e o movimento ad fontes humanista, uma vez que as línguas da antiguidade se tornaram uma clara obsessão também do humanismo alemão. Porém, a diatribe com Erasmo de Roterdã deflagrou uma situação insustentável que parece ter abortado esta aproximação prejudicando para a posteridade as relações entre ambos. Segundo F. Lau, nesta "controvérsia histórica ele se separou do espírito e da fé do humanismo deixando bem claro que fé evangélica é outra coisa que piedade humanista" (LAU, 1974, p. 74). 
Febvre, em suas pesquisas, forma um pressuposto sobre Lutero considerando-o, quando da controvérsia acerca das indulgências (1517), como um indivíduo exposto imediatamente aos fatos históricos, portanto, agindo mais impulsivamente em reação aos mesmos do que como um estudioso agiria, ou seja, com um esquema programático e bem orquestrado de reforma da igreja. Diz ele que "Os acontecimentos, e não sua vontade calculada e reflexiva lhe induziam cada vez mais, a seguir adiante, a manifestar-se, a revelar sua fé” (FEBVRE, 2004, p. 116). Reconhecia, entretanto, que Lutero desejava fortemente partilhar suas descobertas, seus achados escriturísticos, sua "nova hermenêutica”, comunicar "um pouco da febre sagrada que o devorava” (FEBVRE, 2004, p. 116). Purificar sua Igreja por dentro, intramuros. Uma reforma interior atacando as fontes e fundamentos da fé.

Nessa ausência de um programa de reforma, pelo menos nos inícios do movimento reformista, nota-se uma distinção clara, primeiramente em relação à metodologia e à didática humanistas presente em Erasmo e também quanto ao próprio conteúdo do discurso. Por um lado, a voz cristã de Erasmo, entremeada de estoicismo, de uma prudência e sabedoria gregas; ainda que evoque a Jerônimo ${ }^{16}$, o padroeiro dos humanistas; nele a cultura clássica sobrepõe-se ao arcabouço judaico, está cristianizada, guindada ao mundo evangélico e aí se produz "uma moral altruísta, independente do dogma: tesouro com o qual pretendiam certamente enriquecer e adornar um cristianismo humanizado, mais amplo e flexibilizado" (FEBVRE, 2004, p. 117). Erasmo encarnava em toda a Europa letrada esse estereótipo, ensinava uma filosofia de Cristo, professava um Cristo sábio, da concórdia entre os povos e mestre supremo da moral para o banimento definitivo do obscurantismo egresso da Idade Média e ainda infelizmente presente na maioria da população. Sua plataforma era a persuasão educativa a médio e longo prazo.

\footnotetext{
${ }^{16}$ Febvre cita a epístola 501 na qual Lutero afirma que "Para mim, meu dissentimento com Erasmo; provém disto: quando se trata de interpretar as escrituras, prefiro Agostinho sobre Jerônimo na medida exata em que Erasmo prefere Jerônimo sobre Agostinho" (FEBVRE, 2004., p. 120). Em meados de 1516, Erasmo publica sua obra São Jerônimo, em dez volumes em Basiléia, com seu editor Froben.
} 
Por outro, a fala de Lutero, seu sermo de Deo ecoa o profetismo de Israel, a subversão paulina ao cerimonialismo judaico, agora aplicado ao catolicismo medieval e escolástico, como também aos votos monásticos. Sua voz reverbera a patrística, especialmente Agostinho e por isso Febvre identifica uma "impetuosidade embriagada com a qual experimentava no fundo de sua consciência a santidade absoluta de Deus, a onipotência sem limites de sua vontade, a liberdade sem medida de sua misericórdia..” (FEBVRE, 2004, p. 116). Seus achados existenciais e teológicos, por isso mesmo, o impediam de gastar seu tempo nos aspectos exteriores. Seu interesse estava centrado na reconstrução da interioridade cristã de cada indivíduo, abrindo as consciências e os espíritos para a comunhão direta e pessoal com Deus sem mediações humanas.

Obviamente que a aspiração por reforma, segundo Febvre, vinha de longa data como desejo dos humanistas cristãos, conforme já dissemos no início desse ensaio; uma vontade expressa em desenterrar a simplicidade evangélica sepultada pelos séculos de tradição eclesiástica, “invenções humanas” potencializadas por último nas sutilezas escolásticas. Lutero e Erasmo, nesse primeiro momento, enfrentavam um inimigo comum, almejavam um mesmo objetivo, porém, certamente usavam instrumentos distintos. "Liberar da obrigação aos cristãos que devem estar submetidos unicamente à Lei de Deus, eram tendências bastante estendidas entre os sábios e letrados desse tempo" (FEBVRE, 2004, p. 117). Nesse momento, a herança legalista do judaísmo, presente no cristianismo medieval, e traduzida e petrificada nos dogmas e prescrições infindáveis do direito canônico era o inimigo a ser vencido. Lutero e Erasmo estavam concordes nisso. Contudo, Lutero havia encontrado o Deus absconditus, agora, era para ele, revelatus - graça misericordiosa e soberania intocável eram suas marcas. Hoje se sabe que a formação de Lutero o levou a isso. A influência de Johannes Staupitz, superior dos agostinianos no mosteiro de Erfurt onde esteve Lutero por vários anos; os sermões místicos de Johannes Tauler; a leitura da obra "Teologia alemã”, com certeza foram fatores centrais para a "experiência da torre" - turmerlebnis (RAYMANN, 2004, p. 
45) ${ }^{17}$. O seu simul iustus et peccator tão fundamental em sua Rechtfertigung bei Lehre, certamente é oriunda desse núcleo de influência. Oberman, por exemplo, advoga que a dupla existência humana de pecado e justiça, tão forte em Lutero, traduz essa mística; segundo ele, "O encontro com a teologia agostiniana em Staupitz e da experiência mística em Tauler anima e confirma a Lutero em seu caminho para uma nova piedade e uma nova ciência" (OBERMAN, 1992, p. 224). Já Erasmo pensava numa formação cristã do homem moderno, preparando-o para os novos tempos como bem indicou em seu Enchiridion, com forte ênfase numa piedade voluntariosa e com esforço denodado por um comportamento político e social digno da identidade cristã.

Febvre ressalta que o mútuo conhecimento entre os dois protagonistas foi desigual, "Lutero tinha tudo para conhecer e julgar a Erasmo: toda sua obra tão vasta e inconclusa. Para conhecer a Lutero, Erasmo não tinha quase nada" (FEBVRE, 2004, p. 124). Nesse sentido, de seu desconhecimento da personalidade de Lutero, é que Erasmo pensou usar "seu ardor, seu talento, para o êxito da causa que lhe era mais cara: a difusão o progresso de sua filosofia de Cristo" (FEBVRE, 2004, p. 124). No início, portanto, Erasmo estava convencido de que encontrara um aliado para a sua causa. Febvre, de maneira livre e imaginativa, interpreta a "ingenuidade" de Erasmo em relação a Lutero: "Esse é dos meus", para em seguida afirmar:

É um exaltado, sem dúvida; porém, escutem: vou apresentar-lhes, do meu modo, suas queixas e objeções; quando ele falar por minha boca, todos vocês dirão: tem razão. Além do mais, suas críticas são o prefácio de um programa completo de reforma e de renovação. Este programa eu o apresentei desde 1504. E o apresento de novo, em 1518, nesta edição corrigida e revisada do Enchiridion. (FEBVRE, 2004, p. 125)

L. Febvre conclui que, de fato, "em 1518, Erasmo, conhecia muito mal a Lutero" (FEBVRE, 2004, p. 125). Nesses inícios não era prudente que Lutero, sabendo bem como pensava Erasmo e onde sua teologia levava, precipitar uma

\footnotetext{
${ }^{17}$ Raymann (2004), cita a J.M. Reu (1934) e sugere várias datas: primavera de 1513, outono de 1514 ou 1519 ou no decorrer desses anos.
} 
ruptura, pelo simples fato de que Lutero já não estava mais sozinho, as críticas e desejo de reforma já reverberaram forte no ambiente religioso da Alemanha, e facilmente encontrava simpatizantes. Porém, há que se registrar que eram também simpáticos a Erasmo, e Lutero percebe isso. Não deixa de ser um paradoxo, como muitas outras coisas na vida de Lutero, o fato de ter que agir com cautela, logo ele, um profeta. Estava retido pelas circunstâncias, pelo menos por algum tempo. Porém, afirma Febvre, "Erasmo, tampouco era livre. Não era livre para dizer, senão para ver que Lutero não era um de seus defensores; não era livre para denunciar as faltas que via-o cometer" (FEBVRE, 2004, p. 126). Como se diz, "os opostos se atraem”, dois indivíduos de formação intelectual distante, contudo, unidos pelas circunstâncias.

Assim, segundo Febvre, se construiu um importante equívoco na interpretação dessas duas monumentais personalidades, pois parte dos "letrados", diz Febvre, julgavam ser um absurdo que se colocasse os dois em um mesmo lado, um equívoco à custa de um acordo firmado no início da Reforma Protestante. Ele explica: "uma espécie de compromisso que permitia a ação... Um equívoco. Um primeiro equívoco. Logo houve outros, e mais graves.” (FEBVRE, 2004, p. 126127). No entanto, a Alemanha não é, nesse momento, apenas o mundo eclesiástico, simbolizado pelo célebre debate teológico entre Lutero e Johannes Eck. Entre 1518 e 1519 há o processo eleitoral, e toda a trama política envolvendo nobres, burgueses, cavaleiros, autoridades eclesiásticas etc., e que no final sairá vitorioso Carlos de Habsburgo. Segundo Febvre, nesse momento político se exaspera o rompante alemão expresso no grito de liberdade. Ecoa forte o espírito nacionalista germânico, assim entende Febvre, pois o contexto no qual está colocado Lutero é sob "todos os conceitos, da sua raça e do seu país. É radicalmente um alemão, por sua maneira de pensar, de sentir e de atuar” (FEBVRE, 2004, p. 132). Isso está muito claro em seu temperamento e sua performance religiosa e pastoral. Entretanto, sua mensagem é não é apenas para a Alemanha, ele pensava nos cristãos, destaca Febvre, e na reforma da igreja, em sua renovação interna, a partir 
do Evangelho de Cristo, como, aliás, Erasmo, mas sem as amenidades clássicas atenuantes da verdadeira vocação cristã.

As suspeitas de Lutero quanto à piedade de Erasmo se confirmaram quando da publicação do De libero arbitrio (1524) de Erasmo, uma clara propensão ao ceticismo humanista, uma vez que esse movimento filosófico era parte integrante da cultua clássica a ser resgatada pelo humanismo. Em sua obra De servo arbitrio de 1525, responde a tal espírito cético (de Erasmo) com relação à segurança das Escrituras, diz ele:

a Diatribe se esforça de modo singular em afirmar que as Escrituras de Deus são por toda parte ambíguas para não ser forçada a usá-las, afirmando por sua vez como certas as opiniões dos antigos para que lhe seja permitido abusar delas. Certamente uma religião digna de admiração, na qual as palavras de Deus são inúteis e as palavras dos seres humanos úteis!... Creio que para ti, que desprezas a certeza da Sagrada Escritura, tenha sido conveniente esta licenciosidade na interpretação; para nós, porém, que trabalhamos com o fim de firmar as consciências, nada de mais inconveniente, nada de mais nocivo, nada de mais pernicioso nos pode atingir do que esta "conveniência" (LUTERO, 1993, pp. 171-172).

Sobre esse tema, segundo Bayer, Lutero ainda explica que é preciso distinguir "entre a clareza externa e interna da Escritura, sem permitir que haja um divórcio entre as duas. Enquanto Erasmo era a favor de deixar como está aquilo que, em seu teor literal, é incompreensível e "venerá-lo em silêncio místico"” (BAYER, 2007, p. 60). Para Lutero estava em jogo o fundamento da piedade cristã. Construir uma identidade cristã sem uma noção clara das Escrituras como sua base seria como edificar uma casa sobre a areia, para lembrar a parábola de Jesus. Ela certamente não subsistiria em tempos difíceis. A Bíblia não poderia ser tratada como uma literatura qualquer (como queria Erasmo, segundo Lutero), pois depende, por um lado da autoridade de Jesus Cristo, centro da Palavra e, por outro, do testemunho interno do Espírito Santo. A igreja não poderia ser a garantia da Palavra de Deus, como sugeria Erasmo. Parece ser esta a desconfiança fundamental de Lutero para com Erasmo, ao reinterpretar humanisticamente as escrituras. Lutero já havia dito por ocasião de suas conversas com o Cardeal Gajetano (1518) e 
com o polemista Eck (1519) que a Escritura era estancia final.

Posteriormente em Worms, na Dieta (1521), deixa claro que se retrataria somente por argumentos tirados da Escritura. Segundo Strohl, é esse o sentido das palavras Gründe der Heiligen Schrift und der Vernunft (STROHL, 2004, p. 68). Erasmo, na opinião de Lutero, exalava uma espécie de piedade alheia às escrituras, ainda que as utilizasse como artifício retórico para legitimar como cristã uma espiritualidade de fato autônoma, independente da vontade de Deus. Lutero, com base no sacerdócio universal dos crentes, conseguiu dar um salto qualitativo importante para a hermenêutica dos textos sagrados. "A distinção de Lutero parece privilegiar altamente a razão humana na interpretação do texto bíblico independentemente de fontes estabelecidas" (GROSSHANS, 2013, p. 202). Nesse aspecto também Lutero, como outros, antecipava o espírito moderno.

Se Lutero estava desde 1517 em uma pugna interminável com o catolicismo, por conseguinte, acostumado às polêmicas, esse não era o temperamento de Erasmo. O humanista holandês se caracterizava pela ação discreta sem movimentos bruscos e nem alarde coletivo, era um conselheiro de grande confiabilidade e sua sabedoria era conhecida internacionalmente. Dificilmente se envolvia em querelas e sua voz era ouvida como instância última. M. Dreher, ao descrever Erasmo, afirma que ele era "Determinado por sua sensibilidade, que o torna cuidadoso, Erasmo não é categórico. Há coisas que não diz que não afirma. Confessa que, no fundo, é um “cético", mas um cristão obediente que se submete à Bíblia e à sua interpretação pela autoridade da igreja” (DREHER, 2014, p. 254). Na visão de Lutero, esse ceticismo manifestava-se na atitude carente de convicções, assim se expressa, "Por conseguinte, te retribuirei abundantemente minha dívida de gratidão se adquirires maior certeza por meu intermédio” (LUTERO, 1993, p. 19). Ou ainda em ironia sobre sua propalada moderação, "Vê agora, caro Erasmo, para onde nos conduz essa tua teologia tão moderada e amiga da paz!" (LUTERO, 1993, p. 34). Na discussão, ficará manifesto para Lutero que Erasmo devia mais 
respeito e deferência para com a igreja do que para a Bíblia, evidenciando a ausência da verdadeira piedade.

Lutero vinha já alquebrado de batalhas ríspidas e desgastantes, excomungado e anatematizado de sua igreja. De alguma forma, após a publicação do De servo arbítrio, Erasmo não conseguiu mais manter-se equidistante e comedido, foi forçado a se posicionar e nesse afã polarizou-se na grandeza da humanidade, como humanista não havia outro espaço para ele se colocar. Seguiu a trilha deixada por pensadores que o precederam, como Nicolau de Cusa, Pico della Mirandola, Petrarca, Leonardo da Vinci e de seus contemporâneos, Thomas More, Maquiavel, Lefèvre d'Etaples, Montaigne, Rabelais. Lutero, por sua vez, destacava sobremaneira, com base em Paulo (Rom 3,10-18.23; 6,23a) e Agostinho (Civ. Dei XXI,14), a baixeza humana, o arbítrio escravizado pelo pecado. A resposta escrita de Lutero em Latim foi realmente um primor. Ocupou-se de cada um dos textos bíblicos e patrísticos citados por Erasmo, revelando as falácias e sofismas da interpretação humanista. Por ironia do destino, ao sublinhar a dignidade humana dessa maneira, Erasmo levantava a suspeição sobre si de semi-pelagianismo, doutrina condenada como herética pela Igreja e Lutero, já declarado herege, tornava-se um “defensor” da doutrina cristã da própria igreja que o excomungara.

Não obstante todas as diferenças, de concepções, de temperamento e do instrumental utilizado, entre os dois protagonistas, hoje, em uma visão mais dilatada e aprofundada e por trás das evidências periféricas, Lucien Febvre, após a leitura da obra de Andre Meyer (1909), conclui que a reforma de Lutero o aproximava de Erasmo e que o texto de Meyer "nos ajuda muito bem, retrospectivamente, a compreender um fato bem grave do século XVI: o nascimento e a elaboração, entre 1516 e 1520, de um mal-entendido ou, se querem, de um equívoco entre Lutero e os discípulos de Erasmo" (FEBVRE, 2004, p. 123). Para Febvre, portanto, é fundamental que se recupere a "essência", o núcleo vital das duas propostas de reforma que não era outra, senão: 
Volta às fontes puras da religião, na verdade à sua fonte única, o Evangelho traduzido em língua vulgar e posto nas mãos dos fiéis, sem a distinção nefasta entre a casta sacerdotal e a massa dos crentes; supressão dos "abusos" que não se davam o trabalho de definir exatamente em suas causas e em suas origens; sobre fórmulas tão grosseiramente pintadas, não poderiam estar de acordo?... Que houvesse entre eles variantes era possível e até provável. Porém, no fundo, o programa reformista não era o mesmo para Erasmo e seus seguidores? E ninguém, em 1518, deixaria de aceitar a fórmula de A. Meyer em 1907: estava na natureza das coisas que um Lutero se unisse a Erasmo "apesar de algumas divergências que podiam existir entre suas ideias" (FEBVRE, 2004, p. 123).

As ideias de Meyer encampadas por Febvre no sentido de uma reparação do equívoco ao colocar ambos protagonistas em posições inconciliáveis, é coerente com o epílogo do De servo arbitrio. Ali, Lutero, ainda que continue a falar francamente, como em toda obra, despede-se irenicamente de Erasmo como a um irmão em Cristo. Reconhece a importância de Erasmo dizendo, "Admito que és um grande homem e dotado por Deus com muitos dos mais nobres dons, para não falar nos demais, de teu talento, erudição e da eloquência quase milagrosa" (LUTERO, 1993, p. 215). Lutero ainda reconhece em Erasmo um polemista que tratou a questão em seu núcleo central, discutiu a essência e aquilo que realmente importa,

És o único que atacou a questão em si, isso é, a questão essencial... por isso te agradeço de coração... Com este trabalho também prestaste um grande serviço a mim e confesso que te devo muitas coisas, e, por certo, neste sentido, te tenho muita estima e sincera admiração (LUTERO, 1993, p. 215).

Com isso e com tudo o que significou a Reforma para o advento da modernidade no uso que fez do instrumental humanista, não se poderia esperar outra coisa do protestantismo, ainda que em Lutero se perceba um conservadorismo natural nesse primeiro instante do movimento. Se Erasmo possibilitou de novo a leitura do Evangelho sem os acréscimos e penduricalhos da tradição, Lutero conseguiu discernir o núcleo do Evangelho, sua essência mais pura. Assim, no destino de Lutero se imbrica uma piedade antiga, mas que se abre para o novo que chega. O moderno de Lutero invade a vida cotidiana, não apenas redefinindo o sacerdócio, a vocação mundana, como sendo sagrada e alterando o 
conceito de trabalho - Beruf, mas também reconstruindo a própria identidade da piedade cristã, ao recuperar a fé como regula credenti, o crede ut, intelligas de Agostinho e suas expressões correlatas em Anselmo - fides quaerens intellectum, e credo ut intelligam, todas elas subsidiando a síntese genial elaborada por Barth analogia fidei. Nesse sentido, Lutero, pelo menos nos inícios da Reforma, parece pender para um conceito de fé - fides qua creditur ${ }^{18}$ - a fé pela qual se crê, algo subjacente (subjetivo) como na leitura pietista de Lutero, no século XVII. Bultmann afirma, "A fé (fides qua creditur) na qualidade de obediente ouvir da Palavra - isto é da palavra que diz que sou pecador e que em Cristo Deus perdoa meus pecados - é ato livre da decisão" (BULTMANN, 2001, p. 49). Resgata-se a fé como confiança - fiducia e minimiza-se ao máximo o ritualismo cerimonial em detrimento da atitude pessoal do indivíduo coram Deo.

Em Lutero, faz-se da relação pessoal com Deus o caminho simplificado para a construção da piedade cristã. Portanto, o modelo legalista e sacrificial judaico e o do cerimonialismo da cristandade estão postos sob suspeita e na verdade superados pela adesão pessoal ao convite da graça. Após a exposição dos dois arbítrios, o livre (de Erasmo) e o servo (de Lutero), nos esclarece Febvre que os contemporâneos da diatribe "viram a ruptura definitiva, irremediável, do pensamento humanista e do sentimento cristão, tal como Lutero o interpretava” (FEBVRE, 2004, p. 240).

\section{Conclusão}

Erasmo e Lutero, ainda que estivessem sujeitos a uma estrutura cultural e religiosa sufocante, lutaram cada qual com suas armas pela liberdade de pensamento e de expressão. Ambos desejavam a volta às Escrituras em suas línguas originais, segundo eles, uma fonte segura para as interpretações e aplicações do texto sagrado. Uma espécie de idealismo igualmente os colocava do

\footnotetext{
${ }^{18}$ Mais que pertinente a discussão de Bultmann com Hirsch e Herrmann sobre Lutero acerca dessa questão em Crer e entender. Artigos selecionados. São Leopoldo: Sinodal, 2001, pp. 33-61.
} 
mesmo lado na trincheira. Lutero sonhava com a vivência primitiva e simples do Evangelho, com o mínimo necessário de intervenção magisterial, de sacramentos e cerimonialismos, estava horrorizado com o que ele entendia ter a igreja se transformado num mercado de bens terrenos, como anos antes havia observado em Roma e confirmado na questão das indulgências; Erasmo almejava o retorno às fontes da cultura clássica, absorvidas por um cristianismo culto, educativo e formador das massas, entendendo que a filosofia de Cristo podia ser depreendida do Evangelho e forjar um cristianismo não dogmático.

Seguramente buscavam a liberdade do indivíduo, e nesse ponto os programas coincidiam, as agendas se assemelhavam, ainda que em Lutero, era, sobretudo, evidente uma postura dialética impossível de ser enquadrada num programa formal de reforma. Seu movimento se confundiu com o próprio ímpeto alemão, ao passo que Erasmo transformara-se num paladino intelectual da liberdade num plano internacional, encarnando a figura de um grande mestre, a imagem grega de um paidagogos. Lutero trazia consigo o estilo do profetismo, ainda que sua argumentação, no De servo arbítrio, por exemplo, surpreenda pela meticulosidade e argúcia. A surpresa maior, no entanto, era que na questão das Escrituras o princípio da liberdade, tão caro a Lutero, revelou-se mais dilatado. Nos meandros da discussão Erasmo mostrou-se demasiadamente preso ainda à tradição eclesiástica medieval e Lutero, não tendo mais tal compromisso, viu-se livre e desimpedido para vinculá-la diretamente a Jesus Cristo e ao Espirito Santo, possibilitando assim que uma mente sóbria, sensata e fiel pudesse entendê-la corretamente, desde que em comunhão com Deus. Febvre finaliza as reflexões sobre Erasmo e Lutero, reconhecendo que este "cavou com suas mãos, um novo fosso que se estendeu sucessivamente entre o grupo sábio dos erasmistas e essa pequena tropa dos luteranos estritos” (FEBVRE, 2004, p. 240). Esta ficou sendo a posição da tradição luterana até aos nossos dias, ou seja, uma luta pela liberdade da mente humana dentro de umas condições, como já firmado acima. 
Em Lutero, esse compromisso com Deus, com sua Palavra e a subsequente ação do Espirito Santo fundamenta o retorno da dignidade humana, outrora perdida no pecado, como um dom de Deus e transforma o ser humano em um cooperador na manifestação da graça divina. Nada mais próprio a Lutero que isso!

\section{REFERÊNCIAS}

BAYER, Osvald. A teologia de Martim Lutero: uma atualização. São Leopoldo: Sinodal, 2007.

BINGEN, Hildegard von. Scivias (Scito Vias Domini). Conhece os caminhos do Senhor. São Paulo: Paulus, 2015.

BULTMANN, Rudolf. Crer e compreender: artigos selecionados. São Leopoldo: Sinodal, 2001.

DEISSMANN. Adolf. Paul: a study in social and religious history. New York: Harper \& Brothers, 1957 [Paulus. Eine kultur - und religionsgeschichtliche Skizze, Tübingen: Verlag, 1911].

DIONÍSIO AEREOPAGITA, Pseudo Dionísio. Theol. Myst. I,1. In: SPANNEUT, M. Os Padres da Igreja, n. 2 [sécs. IV a VIII]. São Paulo: Loyola, 2002.

DREHER, Martin N. De Luder a Lutero: uma biografia. São Leopoldo: Sinodal, 2014.

EBELING, Gerhard. O pensamento de Lutero. São Leopoldo; sinodal, 1988.

ENGEN, John van. Basic writings. Mahwh-NJ-USA: Paulist Press, 1988.

FEBVRE, Lucien. Erasmo, la contrarreforma y el espirito moderno. Barcelona: Martínez Roca, 1970.

FEBVRE, Lucien. Martin Lutero: un destino. México: FCE, 2004.

FEBVRE, Lucien. O problema da incredulidade no século XVI: a religião de Rabelais. São Paulo: Cia das Letras, 2009.

FISCHER, Heribert. Mística. In: RAHNER, Karl (Ed). Sacramentum Mundi, 4 Barcelona: Herder, 1973.

FISCHER, Joaquim H. Reforma: renovação da igreja pelo evangelho. São Leopoldo: Sinodal/EST, 2006.

GOMES, C. F. Antologia dos santos padres. São Paulo: Paulinas, 1980. 
GREGÓRIO DE NISA, San. Comentario al Cantar de los Cantares. Salamanca: Sígueme, 1993.

GROSSHANS, Hans-Peter. Fé e razão segundo Lutero. In: HELMER, Christine (Ed.) Lutero: um teólogo para tempos modernos. São Leopoldo: Sinodal, 2013.

HARNACK, Adolf . The mission and expansion of christianity in the first three centuries. New York: Harper \& Brothers, 1961.

LAU, Franz. Lutero. São Leopoldo: Sinodal, 1974.

LOEWENICH, Walter von. A teologia da cruz de Lutero. São Leopoldo: Sinodal, 1988.

LUTERO, Martinho. Obras selecionadas 2: O programa da reforma e Escritos de 1520. São Leopoldo/Porto Alegre: Sinodal/Concórdia, 1989.

LUTERO, Martinho. Obras selecionadas 4: Debates e Controvérsias II. São Leopoldo/Porto Alegre: Sinodal/Porto Alegre, 1993.

MAcGRATH, Alister. A revolução protestante. Brasília: Palavra, 2012.

MAROTO, Daniel de. P. História da Espiritualidade Cristã. Madrid: EDE, 1990.

McGINN, Bernard. Os fundamentos da mística. São Paulo: Paulus, 2013.

McGINN, Bernard. The essential writings of Christian Mysticism. New York: Modern Library, 2006.

MEYER, Andre. Etude critique sur les relations d'Erasme et de Luther. Paris: F. Alcan, 1909.

MIETH, Dietmar. Mística. In: EICHER, Peter (Ed). Dicionário de conceitos fundamentais de teologia. São Paulo: Paulus, 1993.

MONTES, Adolfo G. Reforma luterana e tradición católica. Salamanca: UPS, 1987.

OBERMAN, Heiko A. Lutero. Un hombre entre Dios y el diablo. Madrid: Alianza Editorial, 1992.

OSOWSKI, Cecília (org.). Teologia e humanismo social cristão. São Leopoldo: Unisinos, 2000.

QUASTEN, Johannes. Patrologia. Madrid: Bac, 1991.

RAYMANN, Acir. Lutero não é pedagogo, mas teólogo. In: Leopoldo Heimann (org.). Lutero, o teólogo. Canoas-RS: Ed ULBRA, 2004. 
REU, J. M. Luther German's Bible: An Historical Presentation Together with a Collection of Sources. Columbus: Lutheran Book Concern, 1934.

RICE, Howard. Reformed spirituality: an introduction for believers. Louisville: Westminster/John Knox Press, 1991.

ROCHA, Sabrina Magalhães. O Lutero de Lucien Febvre: uma discussão sobre biografia e história da historiografia. História da Historiografia. Ouro Preto, n. 16, p. 280-286, dezembro 2014. [doi: 10.15848/hh.voi16.755]. Disponível em:

<https://www.historiadahistoriografia.com.br/revista/article/view/755/509>. Acesso em: 20 abr. 2016.

SAN BERNARDO. Obras completas - Introducción general y Tratados I. Edición bilíngue. Madrid: BAC, 1993 .

SAN BERNARDO. Obras completas - Sermones sobre el Cantar de los Cantares V. Edición bilíngue. Madrid: BAC, 1987.

SANTO AgOSTINHO. Ouevres Complètes de Saint Agustín. De La Grandeur de L'Ame. Le Bouveret: Abbaye Saint Benoît de Port-Valais, [s.d]. Cap. XXXIII, Les Sept Degrés de la Puissance de L'Ame, n. 70 e n. 74. [Tradução de Raquel Botelho]. Disponível em: http://www.abbaye-saint-benoit.ch/saints/augustin/grandeurame/index.htm. Acesso em: 20 abr. 2016.

SCHWEITZER, Albert. O misticismo de Paulo o apóstolo. São Paulo: Fonte Editorial, 2003.

SPANNEUT, M. Os Padres da Igreja, 2 [sécs. IV a VIII]. São Paulo: Loyola, 2002.

STOLT, Birgit. “A fé do “coração” de Lutero - experiência emoção e razão”. In: Christine Helmer (ed.) Lutero: um teólogo para tempos modernos. São Leopoldo: Sinodal, 2013.

STROHL, Henri. O pensamento da reforma. São Paulo: ASTE, 2004.

TARNAS. Richard. A epopéia do pensamento ocidental: para compreender as ideias que moldaram nossa visão de mundo. Rio de Janeiro: Bertrand Brasil, 2008.

THOMPSON, C. R. El poeta y el místico. Madrid: Torre de la Botica, 1963.

TILLICH, Paul. História do pensamento cristão. São Paulo: ASTE, 1985.

TÜCHLE, Herman. Nueva história de la iglesia, Tomo III - Reforma y Contra reforma. Madrid: Cristiandad, 1987.

VAUCHEZ, André. A espiritualidade na Idade Média ocidental: (sécs. VIII a XIII). Rio de Janeiro: Jorge Zahar Ed., 1995.

VILANOVA, Evangelista. Historia de la teologia Cristiana I. (De los Orígenes al siglo XV). Barcelona: Herder, 1987. 